XVII междунар. науч.-практ. конф. (24-27 мая 2018 г., Барнаул) - Барнаул: Изд-во АлтГУ, 2018. - С. 513-517. - ISSN: 2313-3929.

14. Сорта ирисов // Российское Общество Ириса. [Электронный ресурс] - 2018. 16 июля. - URL: http://ruiris.ru/ Sorta_SIB_Otech_1.htm (дата обращения: 16.07.2018). 15. Iris Classifications // The American Iris Society. [Electronic Resources] - 2018. - 20 июля. - URL: http://www.irises.org/About_Irises/Classifications.html (дата обращения: 20.07.2018). 16. Iris Encyclopedia (SIB) Siberian // The American Iris Society. [Electronic Resources] - 2018. - 20 июля. - URL: http://wiki.irises.org/Sib/WebHome (дата обращения: 20.07.2018).

17. Testované semenáčky SIB kosatců. Siewki SIB irysów pozostawione do obserwacji // Middle-European Iris Society [Electronic Resources] - 2018. - 20 июля. - URL: http:// www.euroiris.net (дата обращения: 20.07.2018).

\title{
WORLD AND DOMESTIC LATEST OFFERS AND TRENDS IN IRIS SIBIRICA BREEDING
}

\author{
Slepchenko N. A., Shoshina Ye. I. \\ Federal State Budgetary Scientific Institution \\ "Russian Research Institute of Floriculture and Subtropical Crops", \\ c. Sochi, Russia, e-mail: slepchenko@vniisubtrop.ru
}

In recent years, the representatives of the genus Iris have been more and more interested; a lot of work has been done to create new cultivars of $I$. sibirica. Registration of iris cultivars at the international level is carried out by the American Iris Society. In order to study modern trends in I. sibirica breeding we analyzed the cultivars registered for the last 10 years (2008-2017) and published on the websites of AIS and the State Commission. As a result, it was found that 246 cultivars were registered, the largest number in $2009-42$ and in $2010-48$. The majority of the registered cultivars belong to the tall-growing group, $49 \%$ (120 pieces) had the height of about $66-85 \mathrm{~cm}$. According to the terms of flowering, $60 \%$ of the cultivars have mediumflowering terms, $24 \%$ - early-flowering terms, and $16 \%$ - late-flowering terms.

Key words: Iris sibirica, introduction, collection, cultivars, world latest offers, breeding.

УДК 634.25:631.527

doi: 10.31360/2225-3068-2018-66-80-86

\section{ИТОГИ ИСПОЛЬЗОВАНИЯ ГЕНОФОНДА ПЕРСИКА ВО ВЛАЖНЫХ СУБТРОПИКАХ РОССИИ}

Смагин Н. Е., Цымбалова А. А.

Федеральное государственное бюджетное научное учреждение «Всероссийский научно-исследовательский институт изветоводства и субтропических культур», 2. Сочи, Россия, e-mail:n_cimb@mail.ru

Показаны результаты сортоизучения 58 сортообразцов персика в коллекции ВНИИЦиСК за период 12 лет (2007-2018 гг.). Обновлён существующий сортимент персика за счёт 10 выделенных перспективных сортов и клонов: сорта - 'Спринголд’, 'Медин Ред’, 'Эрли Блоу', 'Саммерсет', 
Глава 2. Интродукция и сортоизучение

‘Команче', ‘Файэт’ и клоны - 'Ранний Коллинс' ('Николай I'), 'Ранняя заря’, 'Красная заря' и 'Лариса'. Клон 'Лариса' включён в 2018 г. в Госреестр селекционных достижений РФ. Представленные новые сорта и клоны обеспечивают конвейер свежих плодов в течение 2,5 месяца, как за счёт сверхранних сортов ('Спринголд'), так и более поздних ('Файэт'), а также сортов и клонов, плоды которых созревают в промежутках между основными промышленными сортами: ‘Фаворита Мореттини', 'Коллинс', 'Редхавен', 'Ветеран'. Выделенные перспективные сорта и клоны наиболее продуктивные с высокими товарными качествами плодов, наименее требовательные к холоду зимой и теплу весной, которые являются лимитирующими факторами для успешного выращивания персика в субтропиках России. Уточнена методика оценки недостатка холода зимой для персика.

Ключевые слова: персик, сорта, клоны, продуктивность, конвейер свежих плодов.

Персик Persica vulgaris (Mill.) является ценной плодовой культурой в субтропиках России, как наиболее скороплодная, с большим разнообразием сортов различных сроков созревания. Плоды персика самые крупные среди косточковых пород, очень привлекательные по внешнему виду, высоких вкусовых и десертных качеств.

Большое разнообразие сортов даёт возможность обеспечить беспрерывный и длительный конвейер свежих плодов с июня по октябрь. Это позволяет избежать напряжённости при сборе и реализации продукции, способствует сокращению численности рабочих при уборке урожая и холодильных установок для хранения свежей продукции.

За счёт сверхранних и более поздних сроков созревания удлиняется период поступления свежих плодов персика [7]. В настоящее время в субтропической зоне Черноморского побережья срок поступления свежих плодов определен всего лишь 75-80 дней при выращивании 14 сортов персика [5]. В Болгарии, по данным С. А. Косых [1], сложился основной сортимент из 30 сортов с периодом потребления персика 90 дней. И каждые 10-12 лет обновляется сортимент за исключением сорта 'Редхавен', который сохраняется в странах Европы с 1975 г.

В настоящее время в субтропиках г. Сочи выращивается только 4 основных сорта: ранние - 'Фаворита Мореттини' и 'Коллинс', средний - 'Редхавен', позднего срока созревания - 'Ветеран'. По результатам сортоизучения за последние 12 лет выделены 10 перспективных сортов и клонов, созревающих в промежутках между основными сортами, а также раньше или позднее них.

В целом условия для выращивания персика в субтропиках России (г. Сочи) благоприятны. Здесь нет сильных морозов зимой, достаточно солнечных дней и тепла, обилие влаги при сумме годовых осадков до 1500 мм. 
Однако, наличие лимитирующих факторов препятствует успешному выращиванию персика в прибрежной субтропической зоне г. Сочи. Это, прежде всего, недостаток холода зимой и тепла весной во время цветения. Поэтому надо подбирать сорта персика более устойчивые к лимитирующим факторам, а именно с пониженной потребностью в холоде зимой и тепла весной, с хорошей продуктивностью в условиях субтропиков.

Таким образом, в условиях субтропиков России сорт решает успех выращивания персика.

За период 12 лет (2007-2018 гг.) были изучены 58 сортообразцов. Интродуцированы 10 новых сортов в 2014 г. для предварительной оценки и дальнейшего сортоизучения и обновления сортимента персика в следующий 10-12 летний период, как это принято в Европейских странах.

Новый обновлённый сортимент персика опубликован в 2017 г. в виде «Атласа перспективных сортов персика», где отражены 14 сортов с включением 10 новых сортов, выделенных в результате сортоизучения 58 сортообразцов. Из них сверхранних и ранних - 5 сортов, среднего срока созревания - 4 сорта и 1 сорт позднего срока созревания.

В 2018 г. была подтверждена их перспективность (табл. 1), как более продуктивных и устойчивых к лимитирующим погодным факторам (недостатку холода зимой и тепла весной).

Для завершения периода зимнего покоя, когда формируются генеративные органы в цветковых почках (пестики, тычинки, завязь), требуется определенное количество дней или часов с пониженной температурой воздуха.

По У. Чендлеру для многих сортов персика требуется воздействие температуры $+7,2{ }^{\circ} \mathrm{C}$ и ниже в течение $1000-1200$ часов или 7-8 холодных недель [9]. И. М. Ряднова указывает в своей книге «Персик Северного Кавказа», что для развития цветковых почек в зимний период требуется около трёх месяцев с пониженной температурой воздуха [4].

Нами уточнена методика оценки и подсчёта количества холода зимой для персика [6]. В нашей работе началом подсчёта необходимого холода служило наступление первой холодной декады со средне-декадной температурой воздуха $+7,2{ }^{\circ} \mathrm{C}$ и ниже. В зиму 2017-2018 гг. первая холодная декада наступила в ноябре (III декада). И после неё наступил период глубокого покоя, который заканчивается через 80 дней (около трёх месяцев), т. е. первая холодная декада и еще семь декад после неё (до первой декады февраля). В указанную зиму из 8 декад глубокого покоя холодных оказалось только 3 или 720 часов холода. Это третья декада ноября и вторая, третья декады января. Декабрь и первая декада января были тёплыми. 
Глава 2. Интродукция и сортоизучение

Плодоношение персика $(u / 2 a)$

Таблий 1

в зависимости от сорта и лимитирующих погодных факторов

\begin{tabular}{|c|c|c|c|c|c|}
\hline \multirow[b]{2}{*}{ № ח/п } & \multirow[b]{2}{*}{$\begin{array}{l}\text { Название } \\
\text { сортообразца }\end{array}$} & 2008 г. & 2013 г. & 2018 г. & \multirow[b]{2}{*}{$\begin{array}{c}\text { Средний } \\
\text { урожай } \\
\text { за 5-6 лет, } \\
\text { u/2a }\end{array}$} \\
\hline & & $\begin{array}{c}\text { холод } \\
1440 \text { ч } \\
\text { весна }+13,3{ }^{\circ} \mathrm{C} \\
\text { осадки } 36 \mathrm{mм}\end{array}$ & $\begin{array}{c}\text { холод } \\
1200 \text { ч } \\
\text { весна }+9,6{ }^{\circ} \mathrm{C} \\
\text { осадки } 52 \text { мм }\end{array}$ & $\begin{array}{c}\text { холод } 720 \text { ч } \\
\text { весна }+12,4^{\circ} \mathrm{C} \\
\text { осадки } 63 \mathrm{Mм}\end{array}$ & \\
\hline \multicolumn{6}{|c|}{ 1. Более продуктивные и устойчивые сорта } \\
\hline 1. & ‘Спринголд’ & 79,9 & 55,0 & 50,6 & 48,0 \\
\hline 2. & ‘Николай I’ & 87,2 & 70,0 & 50,7 & 50,9 \\
\hline 3. & 'Коллинс' (к) & 106,5 & 67,6 & 65,0 & 58,6 \\
\hline 4. & ‘Эрли Блоу’ & 100,0 & 110,0 & 81,9 & 82,6 \\
\hline 5. & ‘Редхавен' & 106,6 & 98,0 & 85,8 & 79,8 \\
\hline 6. & 'Команче' & 106,6 & 117,0 & 84,5 & 96,0 \\
\hline 7. & 'Саммерсет' & 100,0 & 98,0 & 84,0 & 101,2 \\
\hline 8. & ‘Ветеран’ (к) & 106,6 & 92,3 & 49,5 & 65,3 \\
\hline \multicolumn{2}{|c|}{ S-средний 8 сортов } & 99,2 & 91,1 & 71,6 & 76,1 \\
\hline 9. & ‘Ранняя заря’ & - & 78,0 & 88,4 & 69,3 \\
\hline 10. & ‘Красная заря’ & - & 77,0 & 74,1 & 63,8 \\
\hline 11. & 'Медин Ред’ & - & 139,1 & 83,2 & 74,3 \\
\hline 12. & 'Лариса' & - & 114,0 & 85,8 & 88,3 \\
\hline 13. & ‘Файэт' & - & 37,5 & 64,4 & 61,3 \\
\hline \multicolumn{2}{|c|}{ S-средний 13 сортов } & - & 88,7 & 73,0 & 74,5 \\
\hline & $\mathrm{HCP}_{05}$ & - & - & 5,6 & - \\
\hline \multicolumn{6}{|c|}{ 2. Менее продуктивные и неустойчивые сорта } \\
\hline 1. & 'Харбинджер’ & 106,5 & 20,0 & 64,0 & 42,6 \\
\hline 2. & 'Армголд & 40,0 & 31,0 & 29,6 & 32,6 \\
\hline 3. & 'Санбим’ & 46,6 & 13,0 & 15,6 & 25,3 \\
\hline 4. & ‘Самаркандский-10’ & 79,9 & 36,2 & 6,0 & 30,0 \\
\hline 5. & ‘Зафрани’ & 53,3 & 13,0 & 3,9 & 16,0 \\
\hline 6. & 'Восток-3’' & 66,6 & 14,4 & 27,6 & 37,3 \\
\hline \begin{tabular}{l|l}
7. & \\
\end{tabular} & ‘Бэбиголд’ & 73,3 & 45,5 & 19,5 & 30,5 \\
\hline \multicolumn{2}{|c|}{ S-средний из 7 сортов } & 52,1 & 24,7 & 23,7 & 30,6 \\
\hline \begin{tabular}{l|l}
8. &
\end{tabular} & ‘Лайка’ & - & 58,8 & 16,8 & 20,6 \\
\hline 9. & 'Форма-1' & - & 50,7 & 19,5 & 15,5 \\
\hline 10. & ‘Вэнити' & - & 34,0 & 10,4 & 10,3 \\
\hline 11. & ‘Донецкий белый' & - & 38,7 & 23,4 & 16,5 \\
\hline 12. & ‘Пламенный’ & - & 25,8 & 40,7 & 26,3 \\
\hline \multicolumn{2}{|c|}{$\mathrm{S}$-средний 12 сортов } & - & 31,7 & 23,1 & 25,3 \\
\hline \multicolumn{2}{|c|}{$\mathrm{HCP}_{05}$} & - & - & 1,9 & - \\
\hline
\end{tabular}


Холода в зиму 2017-2018 гг. оказалось очень мало, но весна в период цветения персика была тёплой $+12,4{ }^{\circ} \mathrm{C}$ и это сыграло положительную роль для успешного плодоношения сортов, менее требовательных к холоду зимой и тепла весной. В 2018 г., несмотря на тёплую зиму, они в большинстве своём дали хороший урожай, который в среднем составил 73,0 ц/га - на уровне средней многолетней 74,5 ц/га.

У более требовательных к погодным условиям сортов персика (менее продуктивных и неустойчивых) продуктивность оказалась в 2018 г. очень низкой в большинстве своем, кроме сорта 'Харбинджер', и составила в среднем 23,1 ц/га. Это в 2-3 раза ниже, чем у более продуктивных и устойчивых к погодным условиям сортов (73,0 ц/га).

Сорта персика с более повышенной требовательностью в холоде зимой оказываются более требовательными к теплу весной во время цветения [8]. Особенно это хорошо видно по сорту 'Харбинджер' в таблице 1, когда в 2013 г. температура весной была всего лишь $+9,6^{\circ} \mathrm{C}$, продуктивность составила 20,0 ц/га. При $+13,3{ }^{\circ} \mathrm{C}$ в 2008 г. урожайность этого сорта была высокой 106,5 ц/га, т. е. в 5 раз выше, а в 2018 г. при $+12,4{ }^{\circ} \mathrm{C}$ и наименьшего количества холода (720 часов) урожайность 64,0 ц/га.

Климат 2018 г. отличался весьма тёплой зимой в период 2017-2018 гг. и тёплой весной, жарким летом с осадками всего лишь 35-39 \% от нормы, а температура воздуха на $2,2-3,6{ }^{\circ} \mathrm{C}$ выше нормы. Поэтому созревание плодов всех сортов было на 10-12 дней раньше обычного срока и плоды были меньшего размера.

Наивысшей урожайности достигли сорта с потребностью в холоде не менее 1200 часов. Это такие лучшие и перспективные сорта для субтропиков России как 'Редхавен', ‘Эрли Блоу', 'Медин Ред', 'Саммерсет', Команче' и другие с урожайностью 98-139 ц/га.

Сорта 'Спринголд', 'Ранний Коллинс' ('Николай I'), 'Коллинс', 'Файэт' более требовательны к холоду зимой (не менее 1400 часов). Их многолетняя продуктивность составила 48,0-61,3 ц/га. Эти сорта включены в сортимент лучших и перспективных сортов, поскольку они пока незаменимы другими из имеющегося у нас генофонда.

Из 58 сортообразцов, изучавшихся за последние 12 лет (2007-2018 гг.), 3 сортообразца являются подвоями для персика. Это 'Памирский', 'Сочинский-7', 'Сочинский-17' для семенного размножения. Урожайность косточек невысокая до 40-60 шт. с 8-летнего дерева 'Памирского' и 'Сочинского-17', а 'Сочинский-7' всего 10-15 шт. косточек. Более эффективен подвой АП-1 ('Кубань-86').

Таким образом, сортимент персика в субтропиках России пополнен десятью новыми перспективными сортами: сверхранними 'Спринголд', 'Николай I' ('Ранний Коллинс'), ранними - 'Ранняя заря', 'Медин Ред’, ‘Эрли Блоу’, средними сроками созревания - 'Саммерсет', 'Команче', 'Красная заря', 'Лариса' и поздними - 'Файэт'. 
Глава 2. Интродукция и сортоизучение

Эти новые сорта предназначены для обеспечения более длительного и беспрерывного конвейера поступления свежих плодов персика. Одни сорта раньше созревают ('Спринголд’), другие позже ('Файэт'), остальные 8 сортов созревают в промежутках уже имеющегося сортимента из четырёх сортов. Такой конвейер позволяет рассредоточить по времени валовой продукт плодов персика небольшими разовыми объёмами, требующими в меньшем количестве рабочей силы для уборки урожая и холодильных камер для хранения скоропортящейся продукции.

Недостатком этого конвейера является малое количество сортов позднего срока созревания, а между сортом 'Ветеран' и 'Файэт' 10 дней (с 15-25 августа) нет сорта, заполняющего этот промежуток. На Западе в это время выращивают сорт ‘Элегант Лэди’, сейчас этот сорт завезён из Краснодара и начато его изучение.

Решающую роль для культуры персика в субтропиках России играет подбор сортов с наименьшей потребностью в холоде зимой и тепла весной.

Промышленная культура персика возможна при наличии сортов с потребностью в холоде не менее 1200 часов.

Холод зимой необходим в период прохождения глубокого покоя для формирования генеративных органов с начала первой холодной декады (не выше $+7,2 \ldots+7,5^{\circ} \mathrm{C}$ ) на протяжении около трёх месяцев (80 дней). В каждой холодной декаде 240 часов холода.

Недостаток холода зимой приводит к низкой завязываемости и продуктивности плодов персика.

За последние 12 лет (2007-2018 гг.) в результате сортоизучения подобраны наиболее продуктивные сорта персика, обновлен сортимент персика за счёт новых перспективных сортов.

С пониженной потребностью в холоде зимой (1 200 часов) выделены сорта: 'Редхавен' и его клоны - 'Ранняя заря', ‘Эрли Блоу', 'Красная заря', 'Лариса', а также 'Саммерсет', 'Команче', 'Медин Ред’, 'Ветеран'.

Описание и характеристика перспективных сортов приведены в опубликованном «Атласе перспективных сортов персика» в 2017 г. [5].

Данные 2018 г. подтверждают результаты, полученные в прошлые годы, и перспективность выделенных сортов.

\section{Библиографический список}

1. Косых С.А. Персик в Болгарии // Садоводство, виноградарство и виноделие Молдавии. - 1980. - № 11. - С. 14-16.

2. Программа и методика сортоизучения плодовых и орехоплодных культур. - Орёл. $-1999 .-606$ с.

3. Программа и методика сортоизучения плодовых, ягодных и орехоплодных культур.

- Мичуринск. - 1973. - 492 с.

4. Ряднова И.М. Персик Северного Кавказа. - Краснодар. - 1974. - 126 с.

5. Смагин Н.Е., Абильфазова Ю.С. Атлас перспективных сортов персика / под ред. Н.Н. Карпун. - Сочи: ВНИИЦиСК, 2017. - 48 с. - ISBN: 978-5-904533-20-5.

6. Смагин Н.Е., Абильфазова Ю.С. К вопросу оценки недостатка холода для персика 
Субтропическое и декоративное садоводство (66)

в субтропиках России // Садоводство и виноградарство. - 2015. - № 1. - С. 33-35. ISSN: 0235-2591.

7. Смагин Н.Е., Абильфазова Ю.С. Характеристика сортов персика для импортозамещения // Вестник российской селькохозяйственной науки. - 2016. - № 5. - С. 57-59. - ISSN: 2500-2082.

8. Смыков В.К. Помология, Т. ІІІ. - Киев: Урожай, 1997. - 280 с.

9. Чендлер У. Плодовый сад. Листопадные плодовые культуры. - М: Сельхозгиз, 1960. $-620 \mathrm{c}$.

\title{
RESULTS OF USING PEACH GENE POOL IN THE RUSSIAN HUMID SUBTROPICS
}

\author{
Smagin N. Ye., Tsymbalova A. A. \\ Federal State Budgetary Scientific Institution \\ "Russian Research Institute of Floriculture and Subtropical Crops", \\ c.Sochi,_Russia,e-mail:n_cimb@mail.ru
}

The paper presents the results of studying 58 peach cultivar-samples in the collection of the Russian Research Institute of Floriculture and Subtropical Crops for 12 years (2007-2018). The existing peach assortment was updated due to 10 selected perspective cultivars and clones: cultivars - 'Springgold', 'Medin Red', 'Earley Blow', 'Summerset', 'Comanche', 'Fayette' and clones - 'Ranniy Collins' ('Nicolai I'), 'Rannyaya zarya', 'Krasnaya zarya' and 'Larisa'. In 2018, clone 'Larisa' was included into the State Register of Selection Achievements of the Russian Federation. The new presented cultivars and clones provide a fresh fruit conveyor for 2.5 months, both due to early cultivars ('Springgold') and later ('Fayette'), as well as cultivars and clones whose fruits ripen between the main industrial cultivars: 'Favorita Morettini', 'Collins', 'Redhaven', 'Veteran'. The allocated promising cultivars and clones are the most productive with high commercial qualities of fruit, not very demanding for cold in winter and heat in spring, which are limiting factors for the successful peach cultivation in the Russian subtropics. The method of estimating the lack of cold for peach in the winter is specified.

Key words: peach, subtropics, cultivars, clones, productivity, conveyor of fresh fruits.

doi: $10.31360 / 2225-3068-2018-66-86-90$

\section{НЕКОТОРЫЕ ВИДЫ \\ ALLIUM ПОДРОДА MELANOCROMМYUM В УСЛОВИЯХ ИСКУССТВЕННОГО ФИТОЦЕНОЗА}

Уралов А. И.

Институт ботаники Академии наук Республики Узбекистан,

2. Ташкент, Республика Узбекистан, е-mail: uralov.85@mail.ru

Проведённое в 2016 г. в ботаническом саду г. Ташкента обследование выявило представителей рода Allium. Все обнаруженные виды - луковичные геофиты с эфемероидным типом развития - произрастают на мягких 